\title{
A Sociological View on Marital Satisfaction: Measuring Capabilities
}

\author{
Lesya Zolotnyik \\ Postgraduate Student, Kyiv National Taras Shevchenko University \\ Address: Glushkov ave. 4d, Kyiv, Ukraine 03680 \\ E-mail: alisazolotnyik@gmail.com
}

\begin{abstract}
This article is devoted to demonstrating the capabilities of sociology in the measuring of certain aspects of family life. The study of different aspects of human activity has always been the subject of heated debates across various sciences. Sociology is not an exception. Most often, social scientists study human activity in order to predict social behavior and to build models of these processes. Also, the development of incentive programs which stimulate the growth or the decline of certain indicators in a proper manner has gained popularity in recent times. In the spotlight of this article is mating behavior as one form of human activity, using the concept of marital satisfaction as an empirical referent. The author considers marital satisfaction as a fundamental component of the family-complex study, and proposes to examine the basic sociological methods that are used to investigate this area. For a better understanding of mating behavior, the author touches upon the problems of attitudemeasuring in the use of Likert scale, demonstrates ideas of the R.Udry sociological test, describes the Whitfield's R. «altruistic pyramid», illustrates the scale of love and sympathy, developed by Zeke Rubin, and the Soviet researchers of family as a social institution are also mentioned in this article. Scientific and technological progress also helps in the development of measurement techniques. This kind of measuring procedure is also represented in this article. The idea of developing Data Mining is positioned by the author as a major step in the development of analysis without subjectivity. The conclusion to this article highlights the importance of using multiple methods for a representative study.

Keywords: family, marital satisfaction, attitudes, measuring, love, scale
\end{abstract}

For many decades, human mating behavior has been the main focus of scientists' attention. Great interest is caused by the fact that the marriage rate, as a social phenomenon, has a significant impact on all spheres of human life. However, it poses a question how can sociologists measure human mating behavior? This question may be answered through the development of special tests and the designing of various scales. One of the ways to measure the characteristics of human behavior in marital relationships is to study the level of overall marriage satisfaction. The possibility of finding adequate empirical referents to pinpoint the level of satisfaction with the marriage is still debatable; however, sociology, with the involvement of psychological and statistic expertise, has demonstrated some progress in this area. The issue of measuring the level of satisfaction within marriage is relevant in the study of various aspects in regards to family issues. For example,

\footnotetext{
(C) Zolotnyik L., 2014

(C) Centre for Fundamental Sociology, 2014
} 
defining the level of marriage satisfaction is crucial in studying the way a relationship is formed between spouses, as are examining stabilizing and destabilizing factors in family interactions, measuring the overall family atmosphere, understanding how the child's personality is moulded, etc. It can be assumed that in families with a high level of satisfaction with the marriage that the duration of the marriage will be longer. Given that, social workers, sociologists, demographers, and social politicians should be interested in gathering information on the level of satisfaction within a marriage. We can ask; why are sociologists so interested in measuring marriage satisfaction? Marital satisfaction is the fundamental component of the family-complex study and although marital satisfaction is a component of the family's microclimate. Marital satisfaction is the fundamental component of the family-complex study and a component of the family's interaction. Marital satisfaction can be viewed as an indicator of several aspects of a couple's life, such as the level of mutual understanding, the level of satisfaction with their sex lives, the tightness of communication in the family, and others.

When one speaks about measuring human mating behavior, first of all, it is necessary to identify the attitudes of the couple. The concept of «attitude» has many different interpretations. In general terms, it can be said that attitude refers to the «disposition of individual to view things in certain ways and to act accordingly» (Percy, 1966). Through the analysis of the concept of attitudes in the context of family relationships, it is evident that similar attitudes of the couple promote an increased mutual understanding and improves communication.

Attitudes as a complex of ideas and sentiments can be measured by a special scale, the Likert scale. The Likert scale, proposed in 1932 by Rensis Likert, is one of the three main types of scales for measuring attitudes. It is an ordinal scale of measurement which allows the estimation of the severity of the attitudes, and to compare the intensity of attitudes of different people. The Likert technique presents a set of attitude statements. Subjects are asked to express their agreement or disagreement on a five-point scale. Each degree of agreement is assigned a numerical value from one to five. Thus, a total numerical value can be calculated for all the responses.

The process of the construction of the scale includes the following steps;

1) To form a broad set of statements that express different points of view on the chosen subject/problematics;

2) To select statements that exclude vagueness and ambiguity;

3) To rank selected statements based on personal opinions (agreement-disagreement with statements);

4) To perform statistical calculations of the estimates;

5) To form the final scale, which includes experimental results that demonstrate the most expressed differences in the estimates of the test (Mecheriakov, 2000).

The greatest advantage of the Likert scale is its simplicity, presented in the features of the scale, and the process of the filling-out of questionnaires. Also, its simplicity is manifested in the fact that it is not necessary to involve expert judgment in constructing a scale. But some researchers, such as L. U. Ferguson (and I also support this idea) insist 
on the involvement of experts. In support of this idea, expert assessments contribute to the representativeness of the arguments (attitudes) selection. Secondly, expert assessment allows the evaluation of the "weight of judgments», that is, the intensity of the expression of emotional attitudes. This point is relevant because neutral judgments play no role for the scale, while the extreme indicators are very important. To ensure the functional unity of judgments (when we transfer the selected judgments from the test group to the control group), we must be sure that the respondents in both groups are guided by the same criteria in evaluating judgments. Thus, the problem of choosing the test and control groups is the greatest challenge in the construction of a Likert Scale test.

In summing up the pros and cons of the Likert scale, I would like to quote Y. Tolstova who says «since the degree of respondent's consent with a certain judgment may be different - it would be useful to explore the possibility of building Therstone and Likert scale hybrid» (Tolstova, 1998).

An example of using a Likert scale for studying marital satisfaction studying is found in the cross-sectional study «Marital and Parental Satisfaction of Married Physicians with Children». The results of this study are presented in the Journal of General Internal Medicine (Warde, Moonesinghe, Allen, Gelberg, 1999). Male and female physicians in a southern California county were selected as respondents. Ratings of marital and parental satisfaction were measured on a 5-point Likert scale. One outcome of the study was the result of a mean score for marital satisfaction of 3.92 (from a range of 1.75-5.0). The most important factors that increased marital satisfaction (according to the researchers Carole M. Warde, Kushan Moonesinghe, Walter Allen, and Lillian Gelberg), were supportive spouses, and lower levels of role conflict. In conclusion, I should mention that this study, in my opinion, could be useful in extracting variables which could serve as part of a new research, and that the conclusions of this study may also be useful for understanding the factor of satisfaction in a marriage. Speaking of the prospects for a new study, I suggest that it would be interesting to compare the marital satisfaction in different groups. For example, teachers, engineers, civil servants, and others. This kind of research makes it possible to analyze whether this field of work could exert an influence on marital satisfaction.

Another method of measuring marriage satisfaction belongs to R. Udry, who proposed one of the most popular sociological tests. This test is designed to measure marital satisfaction by using multiple parameters, such as measuring a subject's satisfaction with their sex life, the quality of realization of family roles and responsibilities of the other spouse, the level of agreement on basic family problems, etc. In addition, Udry has developed the idea of «marital alternatives». There are two components of marital alternatives; «1. the ability to replace the present spouse with another of equal or higher quality, and 2. the ability to maintain or improve one's economic status. Special constructed scale for measuring "marital alternatives" included: socioeconomic status, appearance variables, and the number of children» (Udry, 1981). The theory of marriage alternatives can be useful in studying the causes of divorce. Although the Udry model categorized all marital resources (those socio-economic variables related to social prestige and earning capacity), 
and appearance variables (such as attractiveness, neatness, and age). In the Udry model, we can find ideas of exchange theory, which states that every person performs actions in the goal of benefits searching. This kind of model presents the idea of selfish people's lifeway - they always striving to get the best for only themselves, ignoring the other theories that view the phenomenon of love as a major factor in maintaining a marital relationship.

As an example of using the «marital alternatives» model, Udry provides an analysis of married, urban, white couples from a survey of low-and middle-income census tracts in sixteen Standard Metropolitan Statistical Areas. The studies were longitudinal and conducted in 1974, 1977, 1978, and 1979 (Udry, 1981). The author concludes that marital alternatives are good predictors of marital disruption. This study may also be useful in empirically-identified (as used by Udry) indicators such as «spouse replacement» and economic level maintenance. Udry contributed that spouse replacement is the most important predictor of disruption from the wives' scale, while economic level maintenance is the most important predictor from the husbands' scale. Udry devoted several works to the research of the importance of appearance, in 1977 and 1984. Similar ideas can also be found in papers of other authors: B. I. Murstein (1972), P. A. Taylor and N. D. Glenn (1976), M. Webster and J. E. Driskell (1983). Even in modern times, we could ascertain the fact that appearance plays an important role in the choosing of a marriage partner.

When we speak about recent studies in this direction, we are confronted with some transformations. Udry assumed that the presence of an alternative partner occurs in pairs who are in a marriage, but now researchers are more interested in alternative partners that appeared on the premarital stage. For example, popular variations of the 1962 theory of filters by A. C. Kerckhoff and K. E. Davis have been developed (Kerckhoff, Davis, 1962). The main idea of this theory proclaims that in choosing a marriage partner, people use certain filters. Therefore, people use many filters to select the «best candidates». However, we should take into account the emergence of «alternative marriages» (and in this case we can talk about the conservation of Udrian postulates). An example is polyamory, or group marriage. This type of marriages is built on the idea of complementarities, that is, the missing qualities / characteristics of one's pairing is complemented by another pairing. Polyamory refers to open but committed relationships with more than one (same and/or opposite sex) lover or partner (or spouse) simultaneously. It follows that we can state the transformation of ideas about selecting the best marital partner and the embodiment of it in alternative forms of marriage. In this way, we can explain the emergence of new types of marriage by using transformed Udrian theory.

The attempt to study the needs of the couple and the compatibility of the needs of the individual could be viewed as an example of a systemic interpretation of family interaction. British sociologist R. Whitfield used Maslow's «pyramid of needs» to describe the needs of the spouses in a marriage. Whitefield flips Maslow's pyramid, placing «going beyond the "Self“" on the highest level of a human's needs. The author named this process «self-transcendence» (Whitfield, 1990). Mutual satisfaction through self-transcendence is true marital and family love. Based on these statements, Whitfield has developed the method of measuring the level of individual satisfaction through self-transcendence. The 
level of family relationships will depend on the degree of agreement between the individual needs of each family member. At the highest level, Whitfield put the «requirement» of going beyond «I», and named this process «self-transcendence».

This theory shows us something different from the content of previous theories. Here we see the importance of dispositional matches of the spouses. This model is also called the «altruistic pyramid», and, in my opinion, has the characteristics of ethical recommendations. Furthermore, the idea of mutual respect and love in this theory contains a strong emotional component . But, the hierarchization of needs in the context of marital relations and the allocation of such a component as self-actualization and self-transcendence can be interesting for further development. As a method of analysis of the self-actualization process, we should mention the «The Personal Orientation Inventory test». This test was created by E. L. Shostorm in 1964 to measure the values and attitudes that are related to self-actualization. Some measured parameters in this test include; self-support; the value of self-actualization; flexibility of behavior; reactive sensitivity; self-esteem; the acceptance of human nature; adoption of humans aggression; sociability; cognitive needs; creativity; self-acceptance, and others. It is important to note that this test was adapted by the Soviet researchers Y. Aleshina, L. Gozman, M. Zagik, and M. Kroz.

The importance of the feelings of love for a high level of satisfaction with marriage is not a new concept and it is still highly debated (especially when it comes to answering the question «what is love?»). Currently, foreign social psychology is creating a whole range of techniques to measure the level of love. The most popular is the so-called scale of love and sympathy, was developed by Zeke Rubin in 1970. Rubin explains the phenomenon of love by using its three (spell out lower numbers) manifestations. They are passion, intimacy and devotion. He considered that such an approach was more productive than the description of love as emotions, personality traits, etc. In his measurements, Rubin takes into account what kind of feelings prevails, love or sympathy. The scales of love and sympathy by Rubin are represented by two sets of statements. Each statements (scale of love and scale of sympathy) including 13 points in their original forms. The three key components of measurement on this scale are attachment, caring, and intimacy levels within the relationship.

I am assuming that the difficulty of the allocation of the factor of love (as a component of marital satisfaction) contained in the finding of the empirical referents of love. It is difficult to fix such a phenomenon, which has not yet acquired its scientific reaffirmation. Great work regarding «what is love» is found in The Oxford Handbook of Close Relationships (Simpson, Campbell, 2013). I have noted and agreed with an important observation in this book; it might be expected that not everyone conceptualizes love in the same way, so we should mind individual and cultural differences of love. There are many researchers devoted to the analysis of love. S. Klimova, in her work Social Phenomenon of Love (Klimova, 2009), concludes that love exists as a trend that shows human social nature, either developing into a stable phenomenon, or fading away, hardly emerged. This idea can contribute to the explanation of the situation when marital satisfaction decreased 
without apparent reason. This is another line of research related to the question of does love pass over time (Acevedo, Aron, 2009).

In this research, the ideas of $Z$. Rubin and other researchers (the ideas of Laswell and Laswell (1976), Sternberg's passion subscale (1997), the Triangular Love Scale developed by Masuda (2003), and Lund's Short Love Scale (1985)) were used. Selected types of love were coded in a specific way, and the study examined a correlation between these types and the duration of time. As result of the research, the author concluded that «Romantic love was strongly correlated with relationship satisfaction in both short and long-term relationships, whereas obsessive love was slightly correlated with relationship satisfaction in new relationships but very slightly negatively correlated with it in long-term relationships» (Acevedo, Aron, 2009). So, we could establish that researchers are interested in the examination of love. Even if debates continue on the question of «what is love», researchers ascertain that it is an important factor in marriage satisfaction.

Among Soviet scientists, the research of S. Golod should be noted. He found that such factors as love, common interests, and a sense of loneliness are the most popular reasons for entering marriage. Based on this, he demonstrated the interconnection of the motives for marriage with marital satisfaction and, ultimately, with marital stability. He defined marital satisfaction as a result of the implementation of an adequate representation (image) of the family that emerged in the human mind under social influence. S. Golod indicates a correlation of marriage satisfaction and the sexual satisfaction of spouse. Another Soviet scientist, Y. Aleshina, demonstrated that the fundamental criteria of satisfaction in the research of marriage was the duration of the marriage itself. The results of her research have demonstrated that the level of satisfaction within a marriage is a U-shaped curve. «During the first two decades of the family's existence, marital satisfaction decreases gradually, reaching its lowest value in pairs with the experience of family life from 12 to 18, and then increases, but more sharply» (Andreeva, 2004). Important Soviet scholars to note who have developed questionnaires and tests for family study are Y. Aleshina and L. Gozman (Questionnaire «Communication in the Family», 1987), and A. Volkova and T. Trapeznikova («Instructional techniques of diagnosis of marital relations», 2007).

Scientific and technological progress have contributed to the relatively new computerized method of studying family relationships. Professor V. Abrukov, Doctor of Physical and Mathematical Sciences, formulated ideas of Data Mining (DM) and its capabilities in the analysis of family relationships. This method allows the analysis of quantitative and qualitative data simultaneously in order to obtain multifactor models. Abrukov demonstrated his ideas about using Data Mining in the understanding of the family in his article «Happy marriage: analysis and management of family relationships using artificial neural networks» (Abrukov, 2010).

In the field of family studies, (especially while studying the level of marital satisfaction), one should consider several aspects; cultural characteristics, the age of the spouses, the time they have been together, the time they stayed in the marriage, if the couple has children, the social status of the spouses, and so on. 


\section{Conclusions}

In this article, only several methods of measuring marital satisfaction measuring were demonstrated. However, the theories and scales presented in this paper were chosen especially to demonstrate the wide range of the enormous marital sphere. The first mentioned, the Likert scale, became a very substantial sociological instrument. The Likert scale could be useful in measuring social attitudes of the spouses. However, it requires the involvement of other methods in order to provide a deeper analysis in researching the family. Udry, with his research of marriage alternatives, could be useful, too. The necessity of using his theory can be explained by the transformation of marriage and the appearance of new forms of marriage. His «marriage alternative», breaking faith about monogamy, and his remarks about the importance of appearance to build a successful married life are also relevant. R. Whitfield contributed to the study of the family sphere in the context of a deeper analysis of the hierarchic pyramid of the needs of each spouse. It is important to note that many foreign theories demanded adaptation for their success. By taking into account psychological, mental, and national features, such adaptations were successfully accomplished by Soviet sociologists, among them being L. Gozman, Y. Aleshina, M. Zagik, and M. Kroz. Studies of love as a phenomenon stubbornly continue to thrive while causing a lot of discussion. This article has shown that there are many empirical referents for measuring satisfaction with marriage, such as socioeconomic status, appearance variables, the number of children, the duration of marriage, the emotional component (love, passion, affection), sexual satisfaction, and others. Such indicators can be measured with using special scales (the Likert Scale, the Therstone Scale, or Z. Rubin's Scale of Love), or tests (The Personal Orientation Inventory test by E. L. Shostorm, or the Aleshina-Gozman questionnaire «Communication in the Family»). All of these technological measurements can be applied successfully in the context of contemporary research. At the same time, progressive changes in the institution of the family requires an modernization of methodology. As well, a method of mathematical modeling of family relationships has appeared (Data Mining). I believe that this trend needs to be improved, but it is already essential for moving forward in science. At the same time, we must remember that some aspects of family life cannot be studied on the «machine-level». I postulate that the best methodology will be one combining modern technology with the standard procedure of «face to face» interaction.

Having a great scientific arsenal helps to comprehend the depth of family relationships and demonstrate the construction of models of a prognostic nature concerned with the development of these relations. As one of the empirical referents of dispositional personality structure, marriage satisfaction can be measured by applying a variety of techniques and instruments. The selection of the measurement technique will vary depending on various external and internal factors. But for successful deep cognition, it is also important to use more than one technique in the research. In attempting to involve computerized techniques in family-areas analysis, many scientists have developed high-level programs. One obvious advantage is that there is a possibility of an unbiased analysis of 
the situation, but it is important to remember that psychosomatic and socially regulated processes are difficult to trust to computer diagnostics.

\section{References}

Abrukov V. S. (2010) Schastlivyj brak: analiz i upravlenie semejnymi otnoshenijami s pomosh'ju iskusstvennyh nejronnyh setej [Happy marriage: analysis and management of family relationships using artificial neural networks]. Available at: http://www.executive.ru/community/articles/1437975/ (accessed 15 February 2014).

Acevedo, B. P., Aron, A. (2009) Does a long-term relationship kill romantic love? Review of General Psychology, vol. 13, no 1, pp. 59-65.

Aleshina Y., Gozman L., Dubovskaja E. (1987) Social'no-psihologicheskie metody issledovanija supruzheskih otnoshenij [Socio-psychological methods of marital relationships studies], Moscow: Izdatel'stvo MGU.

Andreeva T. (2004) Semejnaja psihologija [Family Psychology], Saint-Petersburg: Rech'.

Carifio J., Perla R. J. (2007) Ten common misunderstandings, misconceptions, persistent myths and urban legends about Likert scales and Likert response formats and their antidotes. Journal of Social Sciences, vol. 3, no 3, pp. 106-116.

Cohen P. S. (1966) Social attitudes and sociological enquiry. British Journal of Sociology, vol. 17 , no 4, pp. 341-352.

Fehr B. (2013) The social psychology of love. The Oxford Handbook of Close Relationships (eds. J. Simpson, L. Campbell), Oxford: Oxford University Press, pp. 201-233.

Golod S. (1984) Stabil'nost' sem'i: sociologicheskij i demograficheskij aspekty [Family Stability: Sociological and Demographic Aspects], Leningrad: Nauka.

Kerckhoff A. C., Davis K. E. (1962) Value consensus and need complementarity in mate selection. American Sociological Review, vol. 27, no 3, pp. 295-303.

Klimova S. V. (2009) Sotsial'nyj fenomen lyubvi [Social Phenomenon of Love]. Sotsiologicheskie issledovaniia, no 9, pp. 79-88.

Murstein B. I. (1972) Physical attractiveness and marital choice. Journal of Personality and Social Psychology, vol. 22, no 1, pp. 8-12.

Rubin Z. (1970) Measurement of romantic love. Journal of Personality and Social Psychology, vol. 16, no 2, pp. 265-273.

Shostrom E. L. (1964) An inventory for the measurement of self-actualization. Educational and Psychological Measurement, vol. 24, no 2, pp. 207-218.

Taylor P. A., Glenn N. D. (1976) The utility of education and attractiveness for females' status attainment through marriage. American Sociological Review, vol. 41, no 3, pp. 484-497.

Tolstova Y. (1998) Izmerenie v sotsiologii [Measurement in Sociology], Moscow: Infra-M. Udry J. R. (1977) The importance of being beautiful: a reexamination and racial comparison. American Journal of Sociology, vol. 83, no 1, pp. 154-16o.

Udry J. R. (1981) Marital alternatives and marital disruption. Journal of Marriage and Family, vol. 43, no 4, pp. 889-897. 
Udry J. R. (1984) Benefits of being attractive: differential payoffs for men and women. Psychological Reports, vol. 54, no 1, pp. 47-56.

Volkova A., Trapeznikova T. (2007) Metodicheskie priemy diagnostiki supruzheskih otnoshenij [Methodic tools for marital relationships diagnostics]. Psihologija sem'i: hrestomatija [The Handbook of the Family Psychology] (ed. D. Raigorodsky), Samara: Bahrah-M, pp. 734-745.

Warde C. M., Moonesinghe K., Allen W., Gelberg L. (1999) Marital and parental satisfaction of married physicians with children. Journal of General Internal Medicine, vol. 14, no 3, pp. 157-165.

Webster M., Driskell, J. E. (1983) Beauty as status. American Journal of Sociology, vol. 89, no 1 , pp. 140-165.

Whitfield R. (1990) Learning to Love: Educational Action for Secure Family Relationships, London: National Family Trust.

\title{
Социологический взгляд на удовлетворенность браком: измерительные возможности
}

\author{
Олеся Золотнюк \\ Аспирант Киевского национального университета им. Тараса Шевченко \\ Адрес: просп. Академика Глушкова, 4Д, Киев, Украина оз680 \\ E-mail: alisazolotnyik@gmail.com
}

Даная статья посвящается рассмотрению возможностей социологического измерения определенных аспектов семейной жизни. Вариация форм человеческой активности всегда являлась предметом острых дебатов разных наук. Социология не исключение. Чаще всего социологи изучают человеческую активность с целью предсказать социальное поведение и сконструировать модель этого процесса. Таким образом, мотивационные программы, которые ориентированны на стимуляцию роста или снижения определенных показателей, являются популярными на сегодняшний день. В центре внимания данной статьи - брачное поведение как одна из форм человеческой активности. В качестве эмпирического референта выступает концепт удовлетворенности браком. Автор рассматривает удовлетворенность браком как основной компонент комплексного исследования семьи и предлагает к рассмотрению основные методы, которые помогают в познании этой сферы. Для лучшего понимания брачного поведения автор затрагивает проблему измерения аттитюдов посредством шкалы Лайкерта, демонстрирует основные идеи теста Р. Удри, «альтруистической пирамиды» Р. Уитфильда, шкалы любви и симпатии 3. Рубина, а также упоминает достижения советских социологов, которые занимались исследованием удовлетворенности браком. Научный и технический прогресс также поспособствовал развитию измерительных технологий. Такого рода техника также упомянута в данной статье. Идея развития «Интеллектуального анализа данных» позиционируется автором как важный шаг к развитию аналитики без вмешательства субъективного фактора. В выводах к данной статье подчеркивается важность использования комплекса методов для более глубокого анализа.

Ключевые слова: семья, удовлетворенность браком, аттитюды, измерение, любовь, шкала 